UDC 930.2(477)

DOI: $10.24919 / 2519-058 x .11 .170712$

\title{
Vitalii YAREMCHUK
}

PhD hab. (History), Professor at Department of History, National University of Ostroh Academy, 2 Seminarska Street, Ostroh, Rivne region, Ukraine, postal code 35800 (vitaliiiaremchuk@gmail.com)

ORCID: http://orcid.org/0000-0003-2493-7271

ResearcherID: C-1039-2019 (http://www.researcherid.com/rid/C-1039-2019)

\section{Віталій ЯРЕМЧУК}

доктор історичних наук, професор кафедри історії Національного університету «Острозька академія», вул. Семінарська, 2, м. Острог, Рівненська обл., Украӥна, індекс 35800 (vitaliiiaremchuk@gmail.com)

Бібліографічний опис статті: Yaremchuk, V. (2019). The problem of ethnicity of Chernyakhiv archeological culture in the scientific heritage of Mykhailo Braichevskyi. Skhidnoievropeiskyi Istorychnyi Visnyk [East European Historical Bulletin], 11, 190-201. doi: 10.24919/2519-058x.11.170712

\section{THE PROBLEM OF ETHNICITY OF CHERNIAKHIV ARCHEOLOGICAL CULTURE IN THE SCIENTIFIC HERITAGE OF MYKHAILO BRAICHEVSKYI}

Summary. The purpose of the research is to determine the viewpoints of a famous archeologist, historian of the ethnic development of Eastern Slavdom Mykhailo Braichevskyi (1924-2001) on the ethnicity of Cherniakhiv archeological culture. The methodology of research includes a comparative historical approach (comparison of the historical concepts of Mykhailo Braichevskyi and other historians), biographical approach (analysis of Mykhailo Braichevskyi's life and career), method of historiographic analysis (specific content of the research papers of Mykhailo Braichevskyi and other Cherniakhiv culture historians) and historiographic synthesis (the formation of the general image of Cherniakhiv culture in the legacy of Mykhailo Braichevskyi). The scientific novelty of the article lies in the fact that for the first time Mykhailo Braichevskyi's concept of the ethnicity of Cherniakhiv culture is reconstructed and the factors that have defined it are stated. Conclusions. As far back as in Soviet times, Mykhailo Braichevskyi developed a framework for the ethnic history of East Slavs staring from the 1st and till the beginning of the 2 nd millennium AD, with the concept of Cherniakhiv population as the Slavs-Antes. The last were regarded by the scientist as the predecessors of the South Western ethnic group of Eastern Slavdom (a conglomerate of six «tribes» called the Polianians) that started to adopt features of the Ukrainian ethnic community in the social and political conditions of the second half of the 1st - the beginning of the 2nd century. While in Soviet times the idea of Cherniakhiv population as the actual Pre-Ukrainians was concealed in terms of a comparatively politically «neutral» historical concept of the ethnic development of Eastern Slavdom, since the beginning of the 1990s, due to the disappearance of government control over historical studies, it has been openly promoted in his research papers.

Key words: Mykhailo Braichevskyi, archeology, historiography, Cherniakhiv culture, ethnicity. 


\title{
ПРОБЛЕМА ЕТНІЧНОЇ НАЛЕЖНОСТІ ЧЕРНЯХІВСЬКОЇ АРХЕОЛОГІЧНОЇ КУЛЬТУРИ В НАУКОВІЙ СПАДЩИНІ МИХАЙЛА БРАЙЧЕВСЬКОГО
}

\begin{abstract}
Анотація. Мета дослідження - встановити зміст і сутність поглядів відомого археолога, історика етнічного розвитку східного слов'янства М. Брайчевського (1924 - 2001 рр.) на етнічну належність черняхівської археологічної культури. В основі методології дослідження - порівняльно-історичний метод (зіставлення історичних конщепцій М. Брайчевського та інших істориків), біографічний метод (аналіз життєвого і творчого шляху М. Брайчевського), метод історіографічного аналізу (конкретного змісту наукових прачь М. Брайчевського та інших істориків з проблем черняхівської культури) та історіографічного синтезу (формування загального образу черняхівської культури в спадщині М. Брайчевського). Наукова новизна статті полягає у тому, що в ній уперше реконструйовано конщепиію М. Брайчевського щзодо етнічної сутності черняхівської культури й аргументовано чинники, які ї̈ визначали. Висновки. М. Брайчевський вже в радянські роки виробив схему етнічної історії східних слов'ян I-початку II тис. нашої ери, складником якої була концепиія черняхівського населення як слов'ян-антів. Останні розглядалися вченим як попередники південно-західного етнічного масиву східного слов'янства (конгломерат шести «племен» під збірною назвою поляни), який в суспільно-політичних умовах другої половини I - початку II тис. набував рис украӥнської етнічної спільності. Якщо в радянські часи ідея про черняхівське населення як фактичних праукрайнців була замаскованою у рамках порівняно політично «нейтральної» історикової концепиії етнічного розвитку східного слов'янства, то з початку 1990-х рр. через зникнення державного контролю над історичною наукою вона почала відверто рекламуватися в його дослідженнях.

Ключові слова: М. Брайчевський, археологія, історіографія, черняхівська культура, етнічна
\end{abstract} належність.

Problem statement. Mykhailo Y. Braichevskyi (1924 - 2001) does not need a special introduction. He is one of a few truly famous Ukrainian historians of the second half of the 20th century, a prominent public figure, an activist of the intellectual opposition to the Communist rule, a truly unique person who belonged to the intellectuals elite of his time. As of today, in honour of Mykhailo Braichevskyi several collections of memoirs and papers about him have been published. Dozens of specific studies are dedicated to his career and pages from his life. The publication of his unpublished legacy has begun. Still, the majority of texts about the scientist, from our perspective, suffer from superficial glorification and even apology of Mykhailo Braichevskyi, against which, we believe, he himself would be the first to protest. Every scientist, especially an outstanding one, such as our hero, deserves respect, which should be shown not only in commemorations but also in a serious attitude towards intellectual legacy - the main treasure, left by the individual of such format, both in life and after passing away in eternity. The necessity of such a «non-jubilee» approach to the comprehension of works of «significant» figures of historical studies is highlighted e.g. by the authors of an interesting article on a famous Soviet archeologist Oleksii Terenozhkin (Sayenko \& Shestakova, 2018). In this article, we will try to show the vision of an archeologist and Eastern Slavdom historian Mykhailo Braichevskyi on one of the most debatable problems in archeology, namely the problem of ethnicity of Cherniakhiv culture. His personality combined rare charms of an extraordinary scientist and a veil of controversy, erudition, unusual for a Soviet scientist, and independence of thought along with insufficient sensitivity to conjuncture (in a broad meaning and in different fields), which, as it seems, sometimes deterred the scientist from intellectual flexibility and ability to reassess his own stand. Due to such features of his own personality, atypical of the mainly conformist 
community of historians in the Soviet times (Yaremchuk, 2018, pp. 243-244), he was the only Ukrainian historian, who evidentially negated the basic constructions of the Soviet historical memory, carefully nurtured in the Stalin times, - a concept of the «Old Rus nationality» (a monography The Origin of Rus) and «reunion of Ukraine with Russia in 1654» (an articlemanifesto Joining or Reunification? Critical Notes Regarding One Concept) (Yaremchuk, 2009, pp. 265-271). These politically motivated historical doctrines are placed by modern science in the museum of relics of the Soviet Imperial historical mythology. Such rigidity of thoughts was as well demonstrated by Mykhailo Braichevskyi in a fierce archeology-based debate, especially in the second half of the 20th century, over the problem, mentioned in the title of the article. However, his ideas did not have and still do not have the total support from professional societies. Actually, we will try to analyze his interpretations of this problem in connection with the corresponding research tradition, which has been developing in a different way and make assumptions about the reasons behind such a collision.

Analysis of the sources and recent studies. The main source of studying Mykhailo Braichevskyi's views on the ethnic nature of Cherniakhiv archeological culture is the texts of the historian, published during $1950-1990$ s, as well as his doctoral thesis The Antes (A Sketch of the History of Eastern Europe in the Era of the Migration Period), unpublished and undefended in the time of preparation for the defense in 1960. The additional light on the scientific and ideological conditions that accompanied Mykhailo Braichevskyi's work is shed by his unpublished correspondence and some other documents of personal and business character from the funds of Ukrainian archives, primarily Fund 320 (The Archive of Mykhailo Braichevskyi) of the Department of Manuscripts of Volodymyr Vernadskyi National Library of Ukraine.

Despite the fact that Mykhailo Braichevskyi was a recognized specialist in archeology and ethnic history of Eastern Europe of the 1st millennium and an author of the original works with regard to these issues, his interpretation of ethnic aspects of Cherniakhiv culture is not represented in any special literature except for the cursory mentions in the articles of Vitalii Yaremchuk (Yaremchuk, 2008, pp. 35-37; Yaremchuk, 2011, pp. 100-101) and synthesis papers of famous Ukrainian (Borys Mahomedov) (Mahomedov, 2001, pp. 1315) and Russian (Mark Shchukin) (Shchukin, 2005, p. 156) scientists-archeologists within «Cherniakhiv» subject. For today, the fullest (from the known to us) synthetic essay stories about the cultural studies, which we will address during the examination of historiographic context and the current status of its investigation, are presented in the abovementioned works and monography of Tetiana Rudych (Rudych, 2014, pp. 10-14), a researcher in the field of anthropological composition of the population of Middle Podniprovia in the 1st2nd millennium, including the population of Cherniakhiv culture. The fact that the works of Borys Mahomedov and Mark Shchukin are the key works on the issue and their conclusions are worth credibility, is stated in the bibliographic note to the entry in The Encyclopedia of Ukrainian History dedicated to this archeological phenomenon, where they were recognized as the principal works for discovering Cherniakhiv culture (Synytsia, 2013, p. 530). The above mentioned predetermined the purpose of research - to identify the content and meaning of Mykhailo Braichevskyi's views on the ethnicity of Cherniakhiv culture, taking into account the context of cultural studies in the world historiography.

Statement of the basic material. Having been discovered at the end of the 19 th - the beginning of the 20th centuries by Vikentii Khvoika, Cherniakhiv culture (or «the culture of burial fields») was at first recognized as exclusively Slavic. The majority of Ukrainian 
and Russian scientists shared this point of view until the 1960s. At the same time, since the beginning of its study by a number of German archeologists, it was determined as a phenomenon, associated with the Germanic people of the Antiquity and Early Middle Ages - the Goths (or, in other interpretations, with the Goths and other Germanic ethnic groups such as the Gepids, the Vandals, the Bastarns etc.), who, according to the established view, had a rather developed political formation during the 3rd-4th millennia in the area that started to be equated with Cherniakhiv culture, the so-called «Ermanaric's state». At the beginning of the cultural studies, its ethnic qualifications were influenced by the researchers' national feelings and political and ideological factors. It was advantageous to interpret extremely unique antiquities and, in general, civilization, atypical of the rest of Eastern European Barbaricum (high-quality ceramic ware, skillfully made jewelry, the prevalence of landbased accommodations etc.) as their own national heritage. Thus, the German scientists, particularly of the Third Reich period, highlighted the civilizational mission of their ancestors, the Germanic-Goths, in the area of Eastern Europe, which allegedly may have been already claimed on legal grounds by the Germanic race in the 20th century. In its turn, starting from the World War II till the mid-1950s, the Soviet researchers added exclusively ideological motivation to the scientific arguments in favour of «autochtonous» origin of Cherniakhiv culture as the pride in the past and worthy opposition to the ideological enemy on the «historical front» were in question. In the prewar and war period, an idea of identifying culture with the nations, famous from the Late Antiquity/Early Middle Ages sources, who were situated in the forest-steppe belt between Dnister and Dnipro and were considered Slavic - the Antes and the Sclaveni, was put forward (Mykhailo Artamonov, Borys Rybakov) (Mahomedov, 2001, p. 13). Accordingly, the idea has been developed that during the times of «Antes' ethnic political formation» from the 1st century AD till the eve of reunification of the East Slavic «tribes» into Ancient Rus) there existed a culture and that there is a direct ethnic and genetic connection between the Cherniakhiv-Antes and Kyivan Rus people.

Liberalization of the political climate in the USSR in the mid-1950s made the appearance of the alternative to «Slavic» versions possible. More and more archeologists were expressing doubts about the distinctly «autochtonous» character of culture. Others adhered to the position of former «ideological enemies» instead, thus defending the common sense of «Gothic» concept. At that time, due to primarily new discoveries of the local character and the increase in awareness of the variety of Cherniakhiv antiquities, an idea, expressed in the Interwar period, was developed about the significant local variability of Cherniakhiv group, and the concept on the cultural polyethnicity appears. Despite the abovementioned information, the majority of specialists in the scientific communities took the «autochtonous»" stand till the 1960s. It was as well supported by the representatives of the party and scientific establishment, particularly by the director of Institute of Archeology of the Academy of Science of the USSR in 1956 - 1987, one of the most influential figures in the post-war Soviet historical studies Borys Rybakov.

Since the beginning of its development, a weak link in the «Slavic» concept has been a small amount of archeological data from those archeological manifestations of the Early Middle Ages, which were considered to be direct Cherniakhiv descendants due to the fact that known to archeologists antiquities of that time were characterized by the «regress» of material, particularly roughly made ware and generally less «civilization». As the opponents of the abovementioned point of view stated (state), the East Slavs of forest-steppe of the Pre-Kyiv Rus age were not ethnic descendants of the Cherniakhiv population. They had predecessors 
in other archeological cultures, which were yet to discover. At last, the «Slavic» concept was substantially undermined in $1960-1970$ s due to the justification of the existence of three Early Slavic cultures in the 6th-7th centuries that was a step backwards in comparison with the Cherniakhivs (Prague-Korchak, Penkiv and Kolochynsk) as well as relatively «poor» so-called Kyiv culture, simultaneous with Cherniakhiv, which began to be regarded as a predecessor of the Kolochynsk and Penkiv cultures. Thus, from the perspective of critics of the concept of «autochtonous and Slavic» nature of Cherniakhiv culture, it «fell out» of the Slavic chain, created by the newly discovered cultures, which combined more outdated (at least according to the archeological antiquities) in comparison with the Cherniakhivs Slavic people of the Antiquity, Early Middle Ages and Old Kyivan age into one (Shchukin, 2005, p. 157).

In $1970-1990 \mathrm{~s}$, the number and areal of the known to scientists Cherniakhiv monuments (there are more than 3500 nowadays) significantly increased. At the same time, the interest of foreign specialists in these problems grew due to the Gothic history and issues of European chronology of the Roman Age. During the last decades, scientists' opinions have significantly come closer. The majority of specialists acknowledge the multiethnicity of culture, the presence of several local variants in it, its late antique («narrow») dating (the 3rd-the beginning of the 5th century), the wide areal of distribution (the south of Eastern Europe, from Romania to Bielhorod and Kursk oblast of Russia), the crucial role of connections with the Roman world in the functioning of the Cherniakhiv population. In the presence of relative consensus on the poliethnicity, the proportions of Germanic and Slavic components and the importance of other ethnic groups (the Scythians, the Sauromatians, the Carpi-Dacians etc) continue to be discussed. For instance, Borys Mahomedov believes that «the Germanic tribes formed the ethnic basis» of culture (Mahomedov, 2001, p. 114). Not completely refuting her previous beliefs, a supporter of the «Slavic» concept, a famous Russian anthropologist Tetiana Aleksieieva started to recognize an important role of the Goths in the Cherniakhivs' ethnogenesis (Alekseeva, 1999). On the contrary, Tetiana Rudych, on the basis of anthropological studies of the Cherniakhiv population of Middle Podniprovia, reached a conclusion on its ethnic diversity even on such a local scale. At the same time, she argues that «people of Germanic decent are occasionally recorded in the area» (Rudych, 2014, pp. 64-65, 222, 224). Recognizing the ethnic heterogeneity of the Cherniakhiv population, Mark Shchukin considered it necessary to emphasize the mystique of the phenomenon of «marvelous solidity of [his] culture on such a vast scale» (Shchukin, 2005, p. 195). At the same time, from the Russian archeologist's perspective, Cherniakhiv archeological culture just as any other was a result of the creativity of both local and newly-arrived people, and «to argue about the priority of those or these was the same as to argue about the benefits of the bicycle rear or front wheel» (Shchukin, 2005, p. 159). In fact, the only known specialist in this problem, who firmly stuck to the «Slavic» concept of Cherniakhiv culture to the end of his days despite some specific views, was Mykhailo Braichevskyi. It is time to give him the word.

Mykhailo Braichevskyi was without a doubt an expert on Cherniakhiv culture. This can be seen from the mentions of him in all of the historiographic reviews of the research on Cherniakhiv culture (Mahomedov, 2001, pp. 13-15; Shchukin, 2005, p. 156; Rudych, 2014, p. 11). The notion is central in his numerous works: from his first unpublished article in 1950 (Braichevskyi, 1950) to one of the last papers published while he was still living - a paper of monographic character The Antes (Braichevskyi, 1998). Apart from that, Mykhailo 
Braichevskyi was the author of the historiographic publications on this topic (Braichevskyi, 1968a; Braichevskyi, 1971; Braichevskyi, 1989b) and provided historiographic stories in the texts about the culture itself.

His views on this question were formed on the verge of 1940 - 1950s under the influence of both scientific tradition and connected with it ideological situation, though he may not realized it at that time. The ideas of that time were developing in accordance with the «Slavic» concept of Cherniakhiv culture. As it was previously mentioned, Borys Rybakov was one of its main promoters, who gained the scientific and political influence in the 1950s. Moreover, during all his scientific career, the Moscow scientist was a famous supporter of the view that the Southern Rus (not the Northern one) served the basis for the Eastern Slavic ethnic group, out of which, according to the concept of the 1940 - the beginning of the 1950s, «Old Rus nationality» - «a cradle» of three «fraternal nations», was formed in Kyivan Rus. His emphasis on Podniprovia as the ethnic center of Eastern Slavdom and future «Old Rus nationality» was objectively «pro-Ukrainian» without Rybakov's striving towards such a provocative under those circumstances treating of the situation. On the other hand, as it will be shown later, Mykhailo Braichevskyi added «bourgeois-nationalist» meaning to the abovementioned idea, at the beginning, probably, without any deliberate intentions. The thing is that while working in the Institute of Archeology of the Academy of Science of the USSR (1948 - 1960), where he applied for immediately after he had graduated from Kyiv University, Mykhailo Braichevskyi was a «faithful» Soviet scientist, who had no reasons to oppose his views to the official mainstream (Yaremchuk, 2008, p. 34; Yaremchuk, 2011, p. 99). It is to be noted that at the very same time, the ideological tendency towards the absolute refusal of «Hrushevskyi's bourgeois-nationalist concept» dominated in Soviet Ukraine, which resulted in an active search by the «fighters of the ideological front» for any «nationalistic» manifestations among the Republican historians. Under such circumstances, the accusations of ideological mistakes were brought against even rather ideologically discreet scholars, as the ideological campaigns in the USSR were developed according to their own logic, which anticipated an extensive network of Soviet country enemies who had to be fought with.

In his first published article in 1950, Mykhailo Braichevskyi instantly rejected the «Gothic» concept as he considered it to be «a product of the German combative imperialism and fascism», «an instrument of exculpating the predatory attempts to conquer our, traditionally, Slavic lands». «Nowadays», the young historian argued without any reservations, «we may consider this theory to be totally disproved» (Braichevskyi, 1950, p. 30). Thus, the thesis on Cherniakhiv culture as a Slavic one, which should have been final and not first, was taken as a baseline. In fact, some particular arguments in its favor were put forward in that article. Moreover, the article provided an outline of his future original concept on the history of Eastern Slavdom in the 1st-the beginning of the 2 nd centuries AD, which was later developed in the 1950-1960s and whose main component was the idea on the Cherniakhivs-Antes. The fundamental principles of this concept were revealed in the article in 1957, (Braichevskyi, 1957), in the already mentioned scientist's undefended «first» doctoral thesis (Mykhailo Braichevskyi became a doctor of historical sciences only during Horbachov's Perestroika (reformation period) in 1989) (DM VNLU, f. 320, a. u. 20) and in the monography The Origin of Rus (Braichevskyi, 1968b). Below is a summary of the concept.

In Mykhailo Braichevskyi's opinion, Cherniakhiv culture included the area of Ukrainian (and partly Moldavan, Eastern Slovak and Southern Polish) forest-steppe and was chronologically limited by the 2 nd-the beginning of the 7 th centuries (the so-called «wide 
chronology»). It was formed on the basis of the more ancient cultural manifestations, namely parts of Pshevorsk, Zarubynetsk and Lypytsk archeological cultures. In addition, according to Mykhailo Braichevskyi, it was exclusively Slavic. Sometimes he briefly spoke in favour of a «softer» version of the «Slavdom» of culture, but this did not change the meaning of his concept. For instance, in The Origin of Rus (1968), the historian emphasized the «marvelous unity and solidity» of culture and «was unable to accept strong statements on the poliethnicity of culture in order to find an effective solution to the problem» (Braichevskyi, 1968b, p. 74). Nevertheless, in one of his publications in 1971, the scientist indicated that «the weight of evidence suggests a contribution of Sarmatian and Celtic culture La Tene [to Cherniakhiv culture]» (Braichevskyi, 1971, p. 101). However, the view on Cherniakhiv ethnic diversity was not developed further in the historian's texts. Cherniakhiv culture was regarded by Mykhailo Braichevskyi as an archeological equivalent to the Slavic ethnos, known as «Antes» and «The Antes' political formation»/ «The Antes' kingdom», which at first was considered an analogy to the other Barbarian European polities on the verge of Antiquity and Early Middle Ages (the Visigothic, Ostrogothic, Burgundian, Vandal etc.) (DM VNLU, f. 320, a. u. 20, pp. 429-430). However, shortly after this, he refused from the analogies with these «kingdoms» (Braichevskyi, 1968b, pp. 152-156).

Unlike «early» strong statements on the impossibility of the «Gothic» concept, in the mid-1950s, Mykhailo Braichevskyi tried to provide sufficient from his perspective arguments for its complete fallacy. Among them, the main argument revolved around uncertainty about the prolonged stay of the Goths in the forest-steppe - a central, in his opinion, areal of the culture spreading. Another argument was the fact of the Goths leaving Nadchornomorshchyna at the end of the 6th century and the existence of culture there till, at the very least, the 5 th century, that is recognized even by the supporters of the "Gothic» attribution to Cherniakhiv (Braichevskyi, 1957, pp. 17-18). Since the end of the 1960s, Mykhailo Braichevskyi has also provided compelling arguments against the thesis on the decay of ceramics on the area of Ukrainian forest-steppe in the Early Middle Ages as an evidence of the absence of Cherniakhiv people there (particularly, he explained the poverty of ceramics, which is considered to be a distinctive feature of Cherniakhiv culture, not by its absence but by the invention of lathe and the dominance of woodenware at that time) (Braichevskyi, 1968b, pp. 36-37; Braichevskyi, 1989b, pp. 123-124).

In the scientist's opinion, the South Western group of East Slavs - the CherniakhivsAntes of the middle of the 1st millennium - was ahead of the North East Slavic tribes in cultural and social and scientific development. However, at the time of the establishment of the East Slavic state in the 9th - 10th centuries, the Northern tribes «in general catch up with their Southern relatives» (DM VNLU, f. 320, a. u. 20, p. 563; Braichevskyi, 1968b, p. 174). A defeat of the Antes' kingdom in the war against the Avars at the beginning of the 7 th century led to the decay of Cherniakhiv culture. Nevertheless, the Antes did not disappear as an ethnos. Under new conditions, they gained a name of the Polianias that, according to Mykhailo Braichevskyi's concept, were not a separate tribe but a union of six tribes - the Ulychians, the Tyvertians, the Dulibians, the Buzhans, the Volynians, the White Crotians (DM VNLU, f. 320, a. u. 20, pp. 131-132; Braichevskyi, 1968b, pp. 135-148, 155, 158). The Antes-Polianians continued to preserve a relative ethnic and political unity even in preKyivan times, forming the so-called «narrow», «primeval» Southern Rus - «the primary cornerstone of the future Rus (Rus in a broad meaning of this word)» (Braichevskyi, 1968b, p. 163). 
According to Mykhailo Braichevskyi, the origins of East Slavic nations formation should be sought in the age of annalistic «tribes». Back then, the Polianian forest-steppe became a center of formation of Ukrainian nationality (the basis of which formed the Polianians, the Siverianians and the Dregovychies), the Upper Dnipro, Oka and Volga - of Russian nationality, and the area of Dregovychi and Polochans - of Belarusian nationality (Braichevskyi, 1968b, pp. 188-189). In the Kyivan Rus era, due to the presence of general East Slavic integration, a strong tendency towards ethnic agglomeration of East Slavs around the three main centers of ethnic formation, Southern, Northern and North-Eastern, continued to exist. Such a situation led to the political disintegration of Kyivan Rus and to the final formation of three East Slavic nations - the Ukrainians, the Belarusians and the Russians (and not vice versa, as the Soviet historians stated, the political disintegration of Rus caused the ethnic disintegration) in the post-Kyivan times. Therefore, formally by the end of the 1980s, Mykhailo Braichevskyi in his work of 1968 had raised doubts about the existence of «Old Rus nationality» in the form of the ethnic monolith (as the official Soviet historiography was doing), without refusing its existence in the Kyivan Rus period. He considered this unity to be rather political than ethnic and regarded it as much more real process of establishing three distinct East Slavic ethnoses in the political framework of one state of Kyivan Rus (Braichevskyi, 1968b, pp. 148, 163-165, 184-185, 188-189, 190-191).

As we can see, the abovementioned historical structures of Myhailo Braichevskyi were based on exclusively scientific arguments and scientific tradition (however, no satisfactory arguments in favour of total rationality of either of «Cherniakhiv» concepts, including Mykhailo Braichevskyi's concept, have been presented till this day) in the Soviet times. Apart from that, almost till the beginning of active persecution of the scientist at the end of the 1960s (because of his signing the so-called «letter 139», addressed to the top officials of the USSR, against the deployment of large-scale political repressions in the country), he enjoyed ideological and intellectual (but not organizational and career) support of Borys Rybakov. The historians were united by the idea of Southern Rus' core in the East Slavic ethnogenesis (DM VNLU, f. 320, a. u. 1522-1526, 1901, 1902). However, two paradoxically opposite in their essence factors worked against Mykhailo Braichevskyi and his views even before he became an unwelcome person for the Communist regime and his mainly servile historiography.

Firstly, it was a relative political liberalization in the post-Stalin times, which gave voice even to the opponents of «Slavic» concept and assisted in a more politically neutral approach to the Cherniakhiv problem and, as a result, activation of corresponding studies and development of alternative interpretations. Secondly, the identification of the Cherniakhivs with the Antes and withdrawal of the central line of the East Slavic ethnogenesis from them was directly related to the forbidden theory of the origin of the Ukrainian people by Mykhailo Hrushevskyi. As it is indicated by the documents, in the 1950s, Mykhailo Braichevskyi was already accused of «repeating» the concepts of the famous Ukrainian historian, demonized by the regime. According to Mykhailo Braichevskyi's unpublished memoirs, several «evil geniuses» who stood guard over «the ideological purity» of the Soviet historical science were working at the Institute of Archeology of the Academy of Science of the USSR at that time. They were irritated by the scientist's Independence and the proximity of his ideas to Mykhailo Hrushevskyi's views, tarnished by «bourgeois nationalism» (DM VNLU, f. 320, a. u. 13, pp. 131-160, 167, 169; a. u. 1522, p. 1; SA IA NASU, f. Dilovodnyi arkhiv [Record keeping archive], d. 1. 1, a. u. 410, pp. 13-123). 
Then why had the historian maintained his scientific positions, formed in the $1950 \mathrm{~s}$, till the end of the Communist regime and ignored both the «liberal» tendencies in the Cherniakhiv history and the calls to get rid of the ideological connection with a dreadful and dangerous enemy of the Soviet historiography? Let us try to give a plausible, from our perspective, answer. When it comes to him ignoring new approaches to the solution of the problem of Cherniakhiv ethnic attribution, then one of the possible explanations may be the following. Mykhailo Braichevskyi had a rather independent and even bold character (that was noted both by his contemporaries and by Braichevskyi himself) (DM VNLU, f. 320, a. u. 13, p. 46; SA IA NASU, f. Dilovodnyi arkhiv [Record keeping archive], d. 1. 1, a. u. 410, pp. 17, 25, 122-123, 150-151; Tolochko, 2006, pp. 36, 87), and such people do not usually abandon their ideas without a legitimate excuse and neglect criticism, especially when they see no reasons for it. Obviously, the scientist did not see such reasons. For this reason, in his texts and statements, he clearly denied Cheniakhiv's «non-Slavic» concepts, not arriving at any compromises and not sparing sarcasm for his opponents. For example, in his article of 1989, he «crushed» the proponents of Cherniakhiv's «poliethnisism» one more time, noting «the unhealthy desire to divide Cherniakhiv culture into local manifestations, where each of them should have obtained an independent ethnic attribution and in such a way, prove the thesis on the Cherniakhiv's multiethnic character» (Braichevskyi, 1989b, p. 117). Over time, the recent ordinary (due to his social and cultural characteristics) Soviet scientist transformed into a historian-oppositionist, one of the volunteers of the national historic heritage, virtually forbidden in Soviet Ukraine (Halishevskyi, 2018). His concept became an expression of not only his exclusively scientific views but also his nationalistic historical thought. If to speak about the scientist's attitude towards Mykhailo Hrushevskyi's ideas, at first, Mykhailo Braichevskyi did not accept the claims of «big brothers» as there was nothing to be «corrected». The archeologist was neither a critic of the Soviet power nor a proponent of the work of the leader of «Ukrainian bourgeois nationalism», and a relative coincidence of their views on the ethnic history of the Early Slavic people did not have any «ideological» premises. However, shortly after that, such accusations started corresponding to reality. Already in the mid-1960s, along with the other pro-opposition Ukrainian historians, he shared a widespread at that environment «cult of Hrushevskyi» as the greatest Ukrainian historian (Braichevskyi, 1996; Rublov, 2007, pp. 233-234, 282). From that time on, Braichevskyi deliberately drew inspiration from it for his unique and more and more distinctly pro-nationalism historical views, the view on the ChekniakhivsAntes in particular.

In general terms, the scientist's ethnogenetic concept did not undergo any changes even after ideological censorship disappearance in the $1980-1990$ s. At that time, Mykhailo Braichevskyi, a scientific legend, historian-nonconformist, formed proponent of the national vision of the Ukrainian past, completely rejected any ideological camouflage and manifested a direct transfer to Mykhailo Hrushevskyi's stand in terms of the Antes as the immediate ancestors of the Ukrainian people. Moreover, he added to the ideas of his predecessor an opinion that «the immediate ancestors of our nation were not only the Antes (that we identify with the annalistic Polianians) but also the Drevlians and the Siverianians, situated more to the north» (Braichevskyi, 1997, p. 57). We cannot satisfactorily explain the total rejection by the venerable scientist of any meaning of the Goths in the genesis of Cherniakhiv culture in the last period of his work in any way, apart from his absolute conviction about self-righteousness and value of the concept of the East Slavic ethnogenesis, 
formulated and stood on for decades during the Soviet regime. What is more, in one of his articles, he formed an extended hypothesis on their non-Germanic ethnic origin and on the fact that the Goths of Nadchornomorshchyna, in fact, were not newly-arrived people from the European North but an autochtonous nation of this region that was forced to leave its ancient territories and start long and fruitful travels throughout Europe after the Huns invasion (Braichevskyi, 1989a). According to our observations, Mykhailo Braichevskyi only in one article of 1992 concisely recognized, at least, the partial presence of non-Slavic people in the Cherniakhiv population one more time (just as in the publication of 1971). «The majority of specialists, at least of the domestic historiography, agree on the fact that Cherniakhiv culture is Slavic completely or partially (along with some other ethnic groups)» (Braichevskyi, 1992, p. 211).

Conclusions. In conclusion, Mykhailo Braichevskyi had already developed a wellorganized and argued framework for the ethnic history of Eastern Slavs since the 1st till the beginning of the 2nd millennium, the component of which was a concept of Cherniakhiv population as the Slavs-Antes, in Soviet times. The last were regarded by the scientist as the predecessors of the South Western ethnic group of Eastern Slavdom (a conglomerate of six «tribes» called the Polianians) that started to adopt features of the Ukrainian ethnic community in the social and political conditions of the second half of the $1 \mathrm{st}$ - the beginning of the 2 nd century. Such views were unacceptable for a part of specialists and political censors due to not only scientific but also political reasons: they corresponded with the views on the origins of the Ukrainian ethnos of the creator of the «nationalist» framework of Ukrainian history Mykhailo Hrushevskyi. Mykhailo Braichevskyi has been convinced of the rationality of his ethnogenetic framework during all his scientific career. His stand was predetermined by two main factors. Firstly, no generally recognized concept of the ethnicity of Cherniakhiv culture has been formulated from the times of Mykhailo Braichevskyi's scientific career and till today. However, a view on the ethnic diversity of the Cherniakhiv population has had the biggest amount of supporters for the last decades. Due to such circumstances, other explanations of this phenomenon, including the concept of Mykhailo Braichevskyi, have upheld their scientific validity. Secondly, the conviction that the mentioned archeological culture is of Slavic nature resulted from the worldview and psychological convictions of the scientist. Mykhailo Braichevskyi belonged to the opponents of the Communist regime in Ukraine, thus by his texts trying to popularize the national vision of the Ukrainian past, effectively prohibited in the USSR. If in Soviet times the idea of Cherniakhiv population as the actual Pre-Ukrainians was concealed in terms of a comparatively politically «neutral» historical concept of the ethnic development of Eastern Slavdom, then since the beginning of the $1990 \mathrm{~s}$, it was advertised openly in his research papers due to the disappearance of government control over historical studies.

The conclusions of this article may be specified by the conduct of further research of Mykhailo Braichevskyi's intellectual biography. For instance, it is worth deepening the examination of the scientific and extrascientific motivations of the scientist as a researcher of Cherniakhiv archeological culture.

Acknowledgments. I express sincere gratitude to all members of the editorial board for consultations provided during the preparation of the article for printing.

Funding. The author received no financial support for the research, authorship, and/or publication of this article. 


\section{BIBLIOGRAPHY}

Alekseeva, T. I. (1999). Etnohenez i etnycheskaia istoryia vostochnykh slavian [Ethnogenesis and ethnic history of the Eastern Slavs]. Vostochnye slaviane. Antropologyia i etnycheskaia istoryia. Moskva: Nauchnyi mir, 307-315. [in Russian].

Braichevskyi, M. (1991 - 1992). Mykhailo Hrushevskyi ta arkheolohiia [Mykhailo Hrushevskyi and archeology]. Ukrainskyj istoryk - Ukrainian historian, 3-4, 1-4, 200-217. [in Ukrainian].

Braichevskyi, M. (1996). Yak my vshanovuvaly Mykhaila Hrushevskoho v den yoho stolittia [How we honored Mikhailo Hrushevskyi on the day of his century]. Ukrainskyj istoryk - Ukrainian historian, 1-4, 319-321. [in Ukrainian].

Braichevskyi, M. (1997). Problema antiv [The problem of the ants]. Ukrainskyj istoryk-Ukrainian historian, 1-4, 56-60. [in Ukrainian].

Braichevskyi, M. (1998). Anty [The Ants]. Ukrainskyj istoryk - Ukrainian historian, 1-4, 26-71. [in Ukrainian].

Braichevskyi, M. Yu. (1950). Arkheolohichni materialy do vyvchennia kultury skhidnoslov'yanskykh plemen VI - VIII st. [Archaeological materials for the study of the culture of the Eastern Slavic tribes VI - VIII centuries]. Arkheolohiia - Archeology, IV, 27-55. [in Ukrainian].

Braichevskyi, M. Yu. (1957). Pro etnichnu prynalezhnist cherniakhivskoi kultury [On ethnic belonging of Chernyakhiv culture]. Arkheolohiia-Archeology, X, 11-24. [in Ukrainian].

Braichevskyi, M. Yu. (1968a). Istoriia vyvchennia cherniakhivskoi kultury [History of study of Chernyakhiv culture]. Istoriohrafichni doslidzhennia v Ukrainskii RSR. Kyiv-Historiographical research in the Ukrainian SSR, (1), 213-238. [in Ukrainian].

Braichevskyi, M. Yu. (1968b). Pokhodzhennia Rusi [The Origin of Rus']. Kyiv: Naukova dumka, 224 p. [in Ukrainian].

Braichevskyi, M. Yu. (1971). [Retsenziia na:] Problemy izuchenyia Cherniakhovskoi kultury [Review on: Problems of studying Chernyakhiv culture]. - Kratkye soobshchenyia Instytuta arkheolohiy AN SSSR - Brief Communications of the Institute of Archeology of the USSR Academy of Sciences, vyp. 121, izd-vo «Nauka», M., 1970. Arkheolohiia - Archeology, 3, 99-103. [in Ukrainian].

Braichevskyi, M. Yu. (1989a). Goty v Nadchornomorshchyni (do postanovky problemy) [Goths in the Black Sea Region (before the problem)], Arkheolohiia - Archeology, 1, 102-114. [in Ukrainian].

Braichevskyi, M. Yu. (1989b). Pro cherniakhivsku kulturu [About Chernyakhiv culture]. Arkheolohiia - Archeology, 2, 115-124. [in Ukrainian].

Department of Manuscripts of Volodymyr Vernadskyi National Library of Ukraine (DM VNLU).

Halishevskyi, V. (2018). Uchast Mykhaila Braichevskoho v antyvladnomu rusi oporu 1960-kh 1970-kh rokiv [Participation of Michailo Braichevsky in the opposing movement of resistance of the 1960s - 1970s.]. Naukovi zapysky Natsionalnoho universytetu «Ostrozka akademiia». Seriia «Istorychni nauky», (27), 145-150. DOI: https://doi.org/10.25264/2409-6806-2018-27-145-150 [in Ukrainian].

Mahomedov, B.V. (2001). Cherniakhovskaya kultura. Problema etnosa [Chernyakhiv culture. Ethnos problem]. Lublin: Wyd-wo Uniwersytetu Marii Curie-Skłodowskiej, 290 p. [in Russian].

of O. Terenozhkin. Skhidnoievropeiskyi Istorychnyi Visnyk - East Europe Historical Bulletin, 9, 54-71. DOI: https://doi.org/10.24919/2519-058x.9.150351 [in English].

Rublov, O. (Comps.). (2007). Instytut istorii Ukrainy NAN Ukrainy: Druhe dvadtsiatyrichchia (1957 - 1977): Dokumenty i materialy [Institute of History of Ukraine of the National Academy of Sciences of Ukraine: The Second Twentieth Anniversary (1957 - 1977): Documents and Materials]. Kyiv, 464 p. [in Ukrainian].

Rudych, T. O. (2014). Naselennia Serednoho Podniprov'ya I - II tysiacholit za materialamy antropolohii [Population of Middle Podniprovia in the 1st-2nd millennium on materials of anthropology]. Kyiv, 298 p. [in Ukrainian].

Sayenko, V. \& Shestakova, N. (2018). The history of study of scientific activity

Scientific archive of Institute of Archeology National Academy of Sciences of Ukraine (SA IA NASU). [in Ukrainian].

Shchukin, M. B. (2005). Gotskiy put: goty, Rim i cherniakhovskaia kultura [Gothic way: Goths, Rome and Chernyakhiv culture]. Sankt-Peterburg: Fylolohycheskyi fakultet Sankt-Peterburgskogo gosudarstvennogo unyversyteta, 592 p. [in Russian]. 
Synytsia, Ye. V. (2013). Cherniakhivska kultura [Chernyakhiv culture]. In V. A. Smolii (Ed.), Entsyklopediia istorii Ukrainy (Vol. 10, pp. 529-530). Kyiv: Naukova dumka. [in Ukrainian].

Tolochko, P. P. (2006). ... I proshloe ne proklynaia [... And the past is not cursing]. Kyev: Art Ek, 232 p. [in Russian].

Yaremchuk, V. (2009). Mynule Ukrainy v istorychnii nautsi URSR pisliastalinskoi doby [The past of Ukraine in the historical science of the Ukrainian SSR after the Stalin era]. Ostroh: Natsionalnyi universytet «Ostrozka akademiia», $526 \mathrm{p}$. [in Ukrainian].

Yaremchuk, V. (2018). Ukrainska radianska istoriohrafiia: suchasnyi stan doslidzhen [Ukrainian Soviet historiography: the current state of research]. Naukovi zapysky Natsionalnoho universytetu «Ostrozka akademiia». Seriia «Istorychni nauky», (27), 242-249. DOI: https://doi.org/10.25264/24096806-2018-27-242-249 [in Ukrainian].

Yaremchuk, V. P. (2008). Chomu Mykhailo Braichevskyi stav istorykom-nonkonformistom [Why Michailo Braichevskyi became a non-conformist historian]. Naukovi zapysky Vinnytskoho derzhavnoho pedahohichnoho universytetu im. Mykhaila Kotsiubynskoho. Seriia: Istorija, (XIV), 33-38. [in Ukrainian].

Yaremchuk, V. P. (2011). Pro fenomenalnist istorychnykh pohliadiv Mykhaila Braichevskoho [On the phenomenal historical views of Mikhailo Braichevskyi]. Hileia: naukovyi visnyk-Gileya: scientific herald, 9, 95-103. [in Ukrainian].

The article was received on March 2, 2019. Article recommended for publishing 10/06/2019. 